\title{
Determination of compatibility and stability of haloperidol and morphine mixtures used in palliative care
}

\author{
Espinosa Bosch María1, Sánchez Rojas Fuensanta², Bosch Ojeda Catalina² \\ ${ }^{1}$ UGC Pharmacy, Regional Universitary Hospital of Málaga, ${ }^{2}$ Department of Analytical Chemistry, Faculty of Sciences, \\ University of Málaga, Spain
}

\begin{abstract}
With the aim of controlling various symptoms, possible to use mixtures of different drugs within infusion devices. This should take into account the compatibility of the mixture. Factors influence the compatibility and stability of the mixtures are: drug type, concentration, solvent, temperature and light. When evaluating the compatibility of the mixtures for infusion for subcutaneous via is important to consider infusion devices used and the conditions of light and temperature should simulate as far as possible the conditions in practice assistance. There are diverse studies that analyze the compatibility of drug mixtures, but there are still many possible combinations of drugs for which evidence is not available. The objective of this work is to study the compatibility and stability of several mixtures of haloperidol and morphine that can be used in solution for subcutaneous infusion.
\end{abstract}

Keywords: Haloperidol/stability/compatibility. Morphine/stability/compatibility. Mixtures. Palliative care.

\section{INTRODUCTION}

Cancer patients who are in the terminal phase simultaneously suffer from various symptoms such as pain, nausea, anxiety, gastrointestinal obstruction and weakness, so that to control these symptoms, simultaneous administration of morphine with other drugs, including haloperidol, is necessary (Schrijvers et al., 1998).

On the other hand, many patients have great difficulty in taking oral medications. In these patients, portable infusion pumps offer the possibility of continuous parenteral administration of drugs while maintaining patient autonomy. To avoid the use of different infusion needles it is very useful to mix different drugs in a single infuser (Graham, Clark, 2005).

In the subcutaneous administration of drug mixtures, by means of infusors, incompatibility thereof or loss of stability may occur. Incompatibility may lead to precipitation or crystallization of the drugs leading

\footnotetext{
*Correspondence: Sánchez Rojas Fuensanta. U/niversity of Málaga, Department of Analytical Chemistry, Faculty of Sciences, Universidad de Málaga, Campus Teatinos s/n, 29071, Málaga, Spain. Phone: +34 952137393. E-mail: fsanchezr@uma.es
}

to cannula blockage, skin irritation and malabsorption (Grassby, Hutchings, 1997).

The physical compatibility and / or stability of mixtures of several drugs in solution for use in subcutaneous infusion has been extensively studied, although in some studies only a visual inspection of the samples was performed, thus obtaining information on the physical compatibility but not on the chemical stability of the drugs in the mixture (Barcia et al., 2003; Barcia et al., 2005; Good, Schneider, Ravenscroft, 2004; Negro et al., 2006; Negro et al., 2007).

Morphine is an opioid analgesic used for the treatment of moderate to severe pain. It is recommended by the WHO for the relief of moderate cancer-related pain. It is the opioid of choice in palliative and terminal care. Morphine is predominantly cleared from body by metabolism to morphine- 3-glucuronide (M3G) and morphine-6-glucuronide (M6G). Haloperidol is a neuroleptic, conventional antipsychotic drug that is part of the butyrophenones.

The objective of this work is to evaluate the compatibility and stability of the mixtures of morphine and haloperidol prepared with $\mathrm{NaCl} 0.9 \%$ at different concentrations stored in elastomeric infusors at $25^{\circ} \mathrm{C}$ and $37^{\circ} \mathrm{C}$ and with protection of light. 


\section{MATERIAL AND METHODS}

\section{Chemical and reagents}

Commercial morphine ampoules of $20 \mathrm{mg} \mathrm{mL}^{-1}$ (Morphine, Braun, Spain) and commercial haloperidol ampoules of $5 \mathrm{mg} \mathrm{mL}^{-1}$ (Dr. Esteve Laboratory, Spain) were employed. Sodium chloride $0.9 \%$ was obtained from Fresenius Kabi, Spain. Other chemical and solvents were of analytical grade and obtained from Sigma-Aldrich, Germany. High purity water (resistivity $18.2 \mathrm{M} \Omega \mathrm{cm}$ ) obtained by a Milli-Q water purification system (Millipore, Bedford, MA, USA) was used throughout this work.

\section{Drug mixtures}

The doses of morphine and haloperidol assayed in the study were chosen taking into consideration those more frequently used by the units of palliative care in our region. The doses assayed were $0.80 \mathrm{mg} \mathrm{mL}^{-1}-0.15 \mathrm{mg} \mathrm{mL}^{-1}, 1.60$ $\mathrm{mg} \mathrm{mL} \mathrm{m}^{-1}-0.15 \mathrm{mg} \mathrm{mL}^{-1}$ and $3.0 \mathrm{mg} \mathrm{mL}^{-1}-0.3 \mathrm{mg} \mathrm{mL}^{-1}$ of morphine and haloperidol respectively, which were prepared in $0.9 \%$ normal saline for injection and stored at two temperatures, $25^{\circ} \mathrm{C}$ and $37^{\circ} \mathrm{C}$ each one, employing a bacteriological and culture oven with temperature and time regulation and digital reading, Selecta (INCUDIGIT 19L 2001246). Each of these six alternatives were prepared in triplicate in elastomeric infuser (type Travenol Baxter $\left.{ }^{\circledR}\right)$ and protected from light. From each mixture, five standards of different concentrations were prepared. The standards were divided into different aliquot parts, stored in Eppendorf tubes and frozen until each analysis day. All the procedures were done under aseptic conditions and using sterile drug solutions. Each day of analysis, the admixtures were conveniently diluted to obtain the concentrations adequate for the final measurement.

\section{Physical stability study}

The physical stability of the samples was assessed by visual examination during all studied days for color change and/or precipitation.

\section{Chemical stability study}

Mixtures concentrations were determined by a stability-indicating HPLC method. HPLC analysis was performed at room temperature $\left(\sim 25^{\circ} \mathrm{C}\right)$ using a Shimadzu LC-6A pump equipped with Rheodine 7125 injection valve $20 \mu \mathrm{L}$, a Shimadzu SPD-6A spectrophotometric detector working at $254 \mathrm{~nm}$. The signal from the detector was recorder and integrated with a chromatography data system Shimadzu C-R6A chromatopac; a LiChrospher ${ }^{\circledR} 100$ C18 $(5 \mu \mathrm{m})$ LiChroCART ${ }^{\circledR}$ 250-4 column was employed. The mobile phase consisted of methanol: $\mathrm{KH}_{2} \mathrm{PO}_{4} 0.05 \mathrm{M}$, adjusted to $\mathrm{pH} 3$ with $\mathrm{H}_{3} \mathrm{PO}_{3}(60: 40$, v/v) delivered at flow rate of $1.0 \mathrm{~mL} \mathrm{~min}^{-1}$. The sample injection volume was $20 \mu \mathrm{L}$, and triplicate injections were performed for every sample. The signal was recorded during 12 minutes and the retention times were 2.8 for morphine and $9.8 \mathrm{~min}$ for haloperidol (Figure 1). The initial concentration of mixture was defined as $100 \%$, and subsequent sample concentrations were expressed as a percentage of the initial concentration. Stability of the mixture was defined as retention of at least $95 \%$ of the initial mixture concentration.

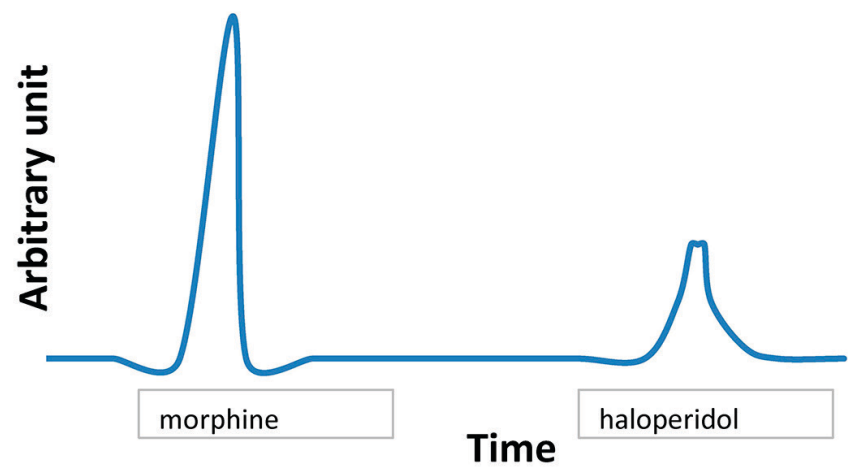

FIGURE 1 - Chromatogram of the admixture morphinehaloperidol.

\section{Forced degradation studies}

Forced degradation study is a complementary part of stability testing where the influence of various stresses factors, such as $\mathrm{pH}$, temperature, light, etc. are investigated (Blessy et al, 2014; Singh et al. 2013).

In this work, five different studies were carried out for this purpose over the mixture solution: acid, base, heat, UV light and hydrogen peroxide.

\section{Compatibility and stability studies}

The compatibility and stability studies were carried out at two different temperatures $\left(25 \pm 0.5^{\circ} \mathrm{C}\right.$ and $37 \pm 0.5^{\circ} \mathrm{C}$ ), and all drug mixtures were protected from direct light exposure. All solutions were assayed in triplicate with three replicates in each case. At different times, the samples were examined for any development and/or change in color. Also, the drug mixtures were examined for signs of precipitation or cloudiness (turbidity) and gas production under bright light against a dark background. 


\section{RESULTS AND DISCUSSION}

\section{Accelerated degradation study}

For the performance of this accelerated degradation study, samples of the morphine-haloperidol mixture have been subjected to specific conditions to evaluate the physical and / or chemical changes that may occur during the analysis. The subsequent studies were made over mixture solutions containing $20 \mathrm{mg} \mathrm{L}^{-1}$ of morphine and $20 \mathrm{mg} \mathrm{L}^{-1}$ of haloperidol.

\section{pH study}

To aliquots of $500 \mu \mathrm{L}$ of mixture were added different amounts of $\mathrm{HCl}$ or $\mathrm{NaOH}(1 \mathrm{M})(100,250$ and $500 \mu \mathrm{L})$. Additions of $\mathrm{HCl}$ have not influence about the chromatographic signal of haloperidol. The area diminishes by effect dilution when the amount of degradant is higher and also the signal is constant with the time. In the case of morphine, the signals are kept constant over time for a volume of $100 \mu \mathrm{L}$, but the influence of $1 \mathrm{M}$ $\mathrm{HCl}$ is observed because increasing the amount of acid added increases the value of the signal at the same time as increasing study time.

With $\mathrm{NaOH} 1 \mathrm{M}$, the haloperidol retention time is shifted to $10 \mathrm{~min}$ while the retention time of the morphine goes to $2.5 \mathrm{~min}$. These signals decrease as the amount of added $\mathrm{NaOH}$ increases and also with the time. In addition, two new signals are obtained at different times that increase over time and the amount of $\mathrm{NaOH}$ added.

\section{Heat study}

Two samples of mixture solutions were heated at different temperatures $\left(40{ }^{\circ} \mathrm{C}\right.$ and $\left.60{ }^{\circ} \mathrm{C}\right)$ during different times (from 5 to 60 minutes). No significant changes were observed in the chromatograms in all cases.

\section{UV light}

A mixture solution was subject to UV irradiation during several days. Retention times of haloperidol and morphine did not vary during the degradation study with ultraviolet light, however, two new signals were obtained at $3.5 \mathrm{~min}$ and $6.5 \mathrm{~min}$, indicating the appearance of degradation products. The signal corresponding to haloperidol decreases as the exposure time increases, while the signal corresponding to the morphine remains constant. The signal at $3.5 \mathrm{~min}$ appears at 52 hours of exposure, while the signal at $6.5 \mathrm{~min}$ appears at 28 hours of exposure, both increase with time.

\section{Oxidant}

To aliquots of $500 \mu \mathrm{L}$ of mixture were added different amounts of $\mathrm{H}_{2} \mathrm{O}_{2} 3 \%(100,250$ and $500 \mu \mathrm{L})$. Additions of $\mathrm{H}_{2} \mathrm{O}_{2}$ have not influence about the chromatographic signal of haloperidol. The area diminishes by effect dilution when the amount of degradant is higher and also the signal is constant with the time. In the case of morphine, the signals increase as the added volume of the oxidizing agent increases, remaining constant with the study time for each volume.

\section{Physical stability study}

All solutions were initially clear and colorless but visible particles appear, in all cases, into the infusers after several days since their preparation. The results are shown in Table I.

\section{Chemical stability study}

Calibration curves were linear over the concentration range used with good correlation coefficients. The linearity of the method was evaluated at five concentration levels injected by triplicate.

All the physically stable solutions were chromatographied. The experimental data were processed making use of the Statgraphics Centurion XVI program. The standard calibration curves exhibited good linearity over the range of concentrations tested, with correlation coefficients greater than 0.999 in all cases as can be seen in Table II. The percentages remaining for each mixture at two studied temperatures $\left(25^{\circ} \mathrm{C}\right.$ and $\left.37^{\circ} \mathrm{C}\right)$ are shown in figures 2, 3 and 4 . Although the admixtures were measured during ten days from the preparation, the figures show the values for the admixtures were they are considered stables (Table I).

TABLE I - Physical stability study

\begin{tabular}{ccccccc}
\hline \multirow{2}{*}{$\begin{array}{c}\text { Turbidity } \\
\text { appearance }\end{array}$} & \multicolumn{5}{c}{ Morphine-Haloperidol $\left(\mathrm{mg} \mathrm{mL}^{-1}\right)$} \\
\cline { 2 - 7 } & \multicolumn{2}{c}{$0.8-0.15$} & \multicolumn{3}{c}{$1.6-0.15$} & $3-0.3$ \\
\hline Days & $25^{\circ} \mathrm{C}$ & $37^{\circ} \mathrm{C}$ & $25^{\circ} \mathrm{C}$ & $37^{\circ} \mathrm{C}$ & $25^{\circ} \mathrm{C}$ & $37^{\circ} \mathrm{C}$ \\
\hline & 9 & 8 & 4 & 7 & 3 & 6 \\
\hline
\end{tabular}


TABLE II - Regression equations for admixtures

\begin{tabular}{|c|c|c|c|}
\hline $\begin{array}{l}\text { Admixtures Morphine- } \\
\left.\text { Haloperidol (mg mL }{ }^{-1}\right)\end{array}$ & Temperature & Drug & Regression equation \\
\hline \multirow{2}{*}{$0.8-0.15$} & \multirow{2}{*}{$25^{\circ} \mathrm{C}$} & Morphine & $\begin{array}{c}\text { Slope: } 3098.1 \pm 23.6^{\mathrm{a}} \\
\text { Intercept: } 2676.6 \pm 1862.7^{\mathrm{a}} \\
\mathrm{R}^{2}=0.9998\end{array}$ \\
\hline & & Haloperidol & $\begin{array}{c}\text { Slope: } 12158.3 \pm 122.3^{\mathrm{a}} \\
\text { Intercept: }-16345.0 \pm 1805.4^{\mathrm{a}} \\
\mathrm{R}^{2}=0.9997\end{array}$ \\
\hline \multirow{2}{*}{$0.8-0.15$} & \multirow{2}{*}{$37^{\circ} \mathrm{C}$} & Morphine & $\begin{array}{c}\text { Slope: } 2246.9 \pm 40.7^{\mathrm{a}} \\
\text { Intercept: } 13822.2 \pm 3568.8^{\mathrm{a}} \\
\mathrm{R}^{2}=0.9993\end{array}$ \\
\hline & & Haloperidol & $\begin{array}{c}\text { Slope: } 15371.0 \pm 92.1^{\mathrm{a}} \\
\text { Intercept: }-39599.1 \pm 1514.5^{\mathrm{a}} \\
\mathrm{R}^{2}=0.9999\end{array}$ \\
\hline \multirow{4}{*}{$1.6-0.15$} & \multirow{2}{*}{$25^{\circ} \mathrm{C}$} & Morphine & $\begin{array}{c}\text { Slope: } 2128.5 \pm 32.6^{\mathrm{a}} \\
\text { Intercept: } 20394.6 \pm 5141.4^{\mathrm{a}} \\
\mathrm{R}^{2}=0.9993\end{array}$ \\
\hline & & Haloperidol & $\begin{array}{c}\text { Slope: } 15225.4 \pm 435.7^{\mathrm{a}} \\
\text { Intercept: }-43010.0 \pm 7160.2^{\mathrm{a}} \\
\mathrm{R}^{2}=0.9990\end{array}$ \\
\hline & \multirow{2}{*}{$37^{\circ} \mathrm{C}$} & Morphine & $\begin{array}{c}\text { Slope: } 2112.8 \pm 32.3^{\mathrm{a}} \\
\text { Intercept: } 35730.5 \pm 5669.3^{\mathrm{a}} \\
\mathrm{R}^{2}=0.9995\end{array}$ \\
\hline & & Haloperidol & $\begin{array}{c}\text { Slope: } 15118.6 \pm 36.3^{\mathrm{a}} \\
\text { Intercept: }-37417.1 \pm 597.9^{\mathrm{a}} \\
\mathrm{R}^{2}=0.9999\end{array}$ \\
\hline \multirow{4}{*}{$3-0.3$} & \multirow{2}{*}{$25^{\circ} \mathrm{C}$} & Morphine & $\begin{array}{c}\text { Slope: } 2203.1 \pm 20.2^{\mathrm{a}} \\
\text { Intercept: } 18861.4 \pm 2571.3^{\mathrm{a}} \\
\mathrm{R}^{2}=0.9997\end{array}$ \\
\hline & & Haloperidol & $\begin{array}{c}\text { Slope: } 16420.9 \pm 324.9^{\mathrm{a}} \\
\text { Intercept: }-39659.2 \pm 4136.3^{\mathrm{a}} \\
\mathrm{R}^{2}=0.9990\end{array}$ \\
\hline & \multirow{2}{*}{$37^{\circ} \mathrm{C}$} & Morphine & $\begin{array}{c}\text { Slope: } 2182.0 \pm 36.1^{\mathrm{a}} \\
\text { Intercept: } 13553.8 \pm 4599.9^{\mathrm{a}} \\
\mathrm{R}^{2}=0.9992\end{array}$ \\
\hline & & Haloperidol & $\begin{array}{c}\text { Slope: } 15574.3 \pm 588.5^{\mathrm{a}} \\
\text { Intercept: }-34825.0 \pm 8187.6^{\mathrm{a}} \\
\mathrm{R}^{2}=0.9990\end{array}$ \\
\hline
\end{tabular}

${ }^{\text {a }}$ Standard error for regression equation obtained by Statgraphic program

\section{CONCLUSIONS}

The administration of mixtures in palliative care has become increasingly popular over the last years. Some mixtures of drugs have proven stability, but there is lack of evidence about the stability and compatibility of the combination of haloperidol-morphine at different concentrations stored into infuser. After this study we concluded that morphine and haloperidol mixtures in saline solution are stable for at least three days when stored in an elastomeric infuser at room temperature or near body temperature in a concentration range of 0.15 $0.8 \mathrm{mg} \mathrm{mL}^{-1}$ and $0.3-3.0 \mathrm{mg} \mathrm{mL}^{-1}$ haloperidol-morphine respectively. 


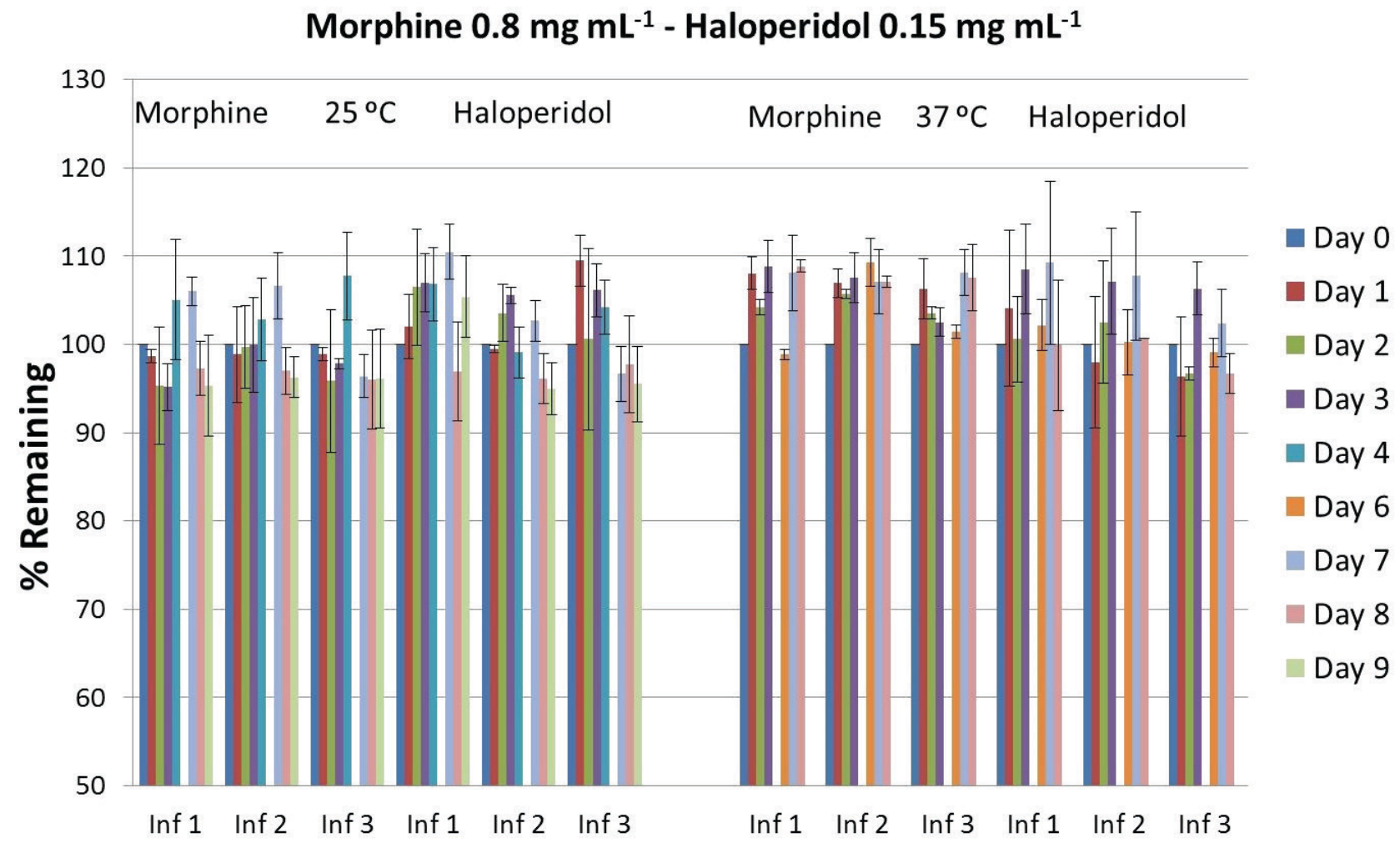

FIGURE 2 - Percentages of mixtures remaining at $25^{\circ} \mathrm{C}$ and $37^{\circ} \mathrm{C}$.

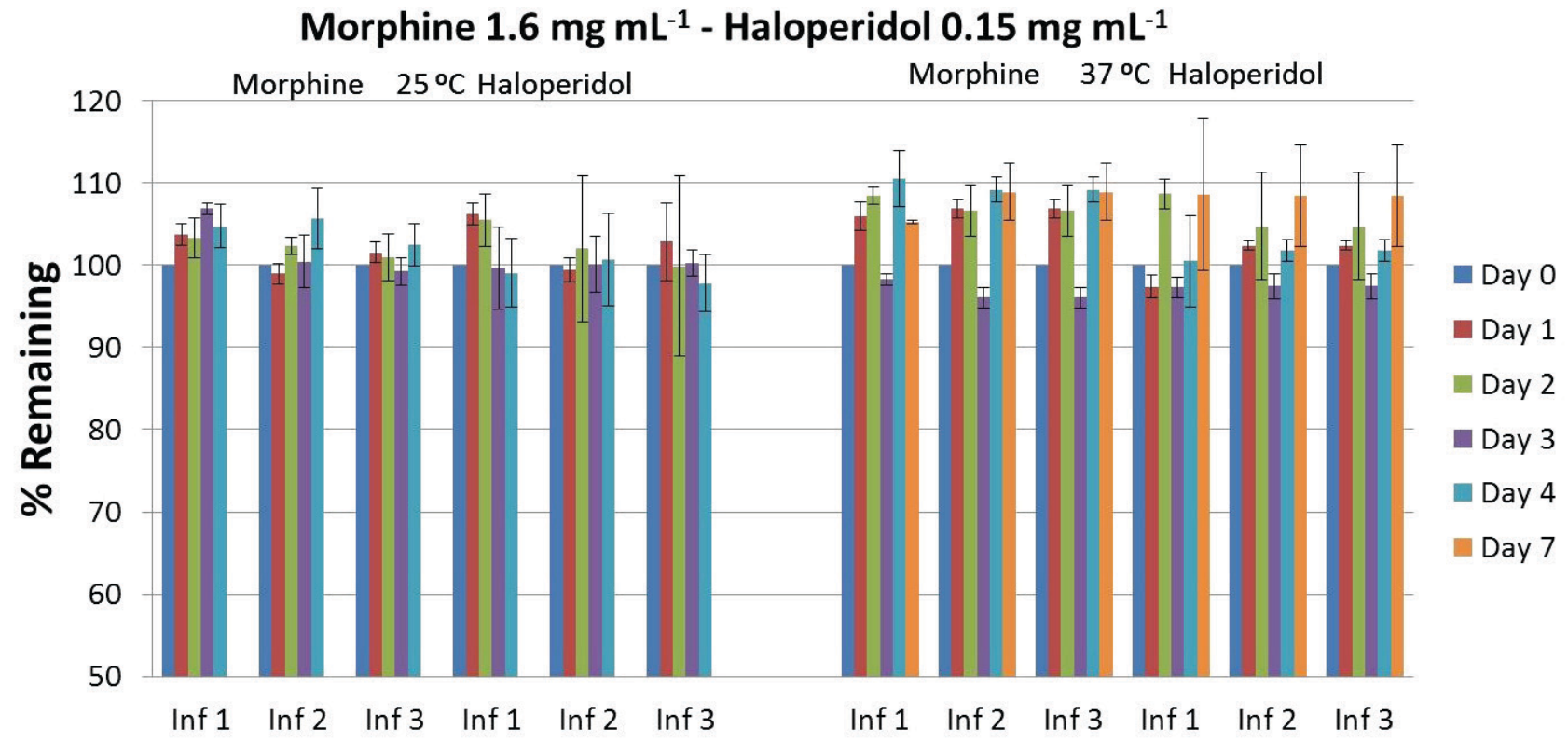

FIGURE 3 - Percentages of mixtures remaining at $25^{\circ} \mathrm{C}$ and $37^{\circ} \mathrm{C}$.

\section{ACKNOWLEDGEMENTS}

The authors thank to Consejería de Igualdad Salud y Políticas Sociales (Junta de Andalucía) for supporting this study (PI-0012-2013)

\section{COMPETING INTERESTS}

Authors have declared that no competing interests exist. 


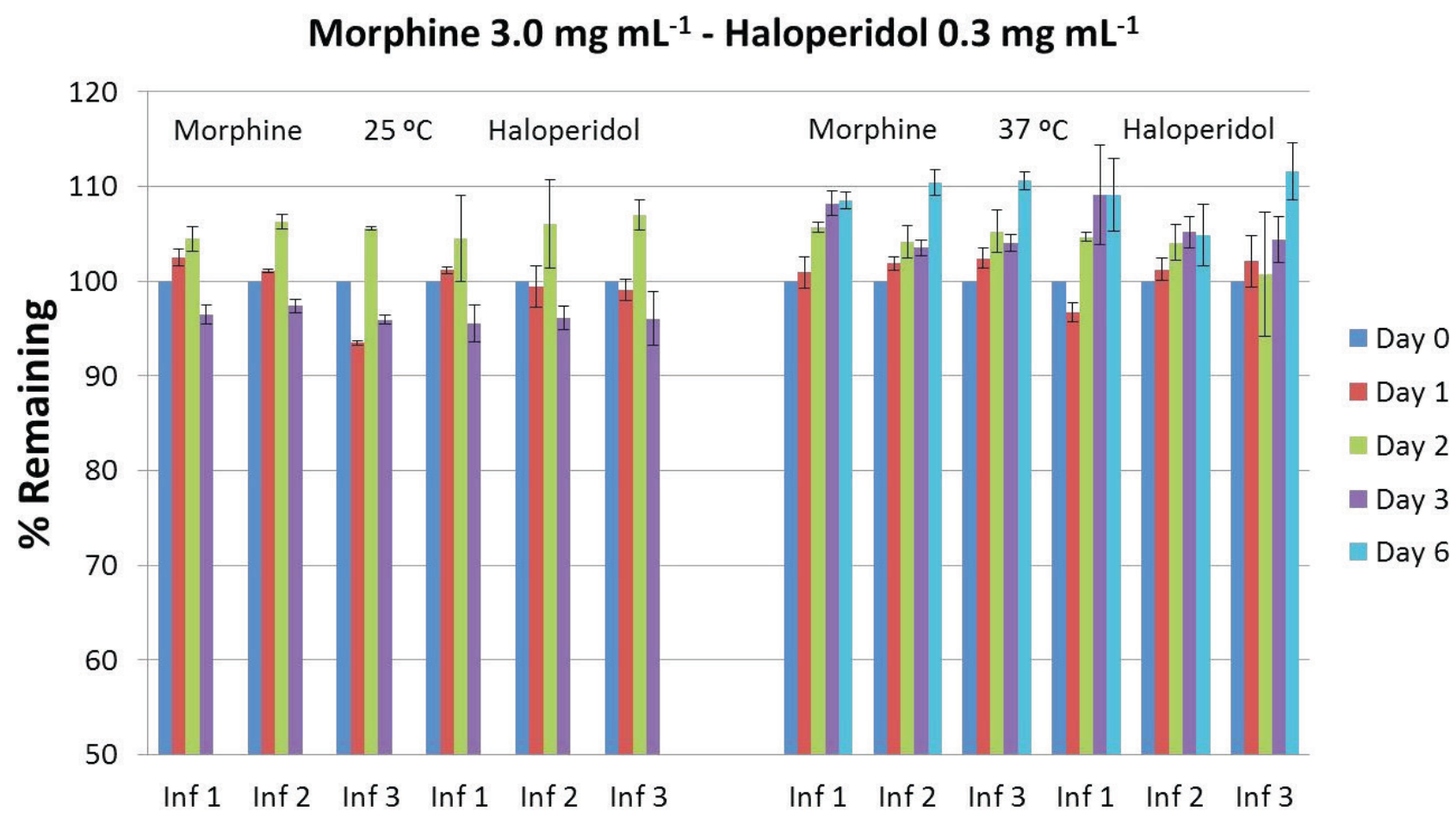

FIGURE 4 - Percentages of mixtures remaining at $25^{\circ} \mathrm{C}$ and $37^{\circ} \mathrm{C}$.

\section{REFERENCES}

Barcia E, Reyes R, Azuara ML, Sánchez Y, Negro S. Compatibility of haloperidol and hyoscine-N-butyl bromide in mixtures for subcutaneous infusion to cancer patients in palliative care. Support Care Cancer. 2003;11(2):107-113.

Barcia E, Reyes R, Azuara ML, Sánchez Y, Negro S. Stability and compatibility of binary mixtures of morphine hydrochloride with hyoscine-N-butyl bromide. Support Care Cancer. 2005;13(4):239-245.

Blessy M, Patel RD, Prajapati PN, Agrawal YK. Development of forced degradation and stability indicating studies of drugs-A review. J Pharm Anal. 2014;4(3):159-165.

Good PD, Schneider JJ, Ravenscroft PJ. The compatibility and stability of midazolam and dexamethaxone in infusion solutions. J Pain Symptom Manage. 2004;27(5):471-475.

Graham F, Clark D. The syringe driver and the subcutaneous route in palliative care: the inventor, the history and the implications. J Pain Symptom Manage. 2005;29(1):32-40.

Grassby PF, Hutchings L. Drugs combinations in syringe drivers: the compatibility and stability of diamorphine with cyclizine and haloperidol. Palliat Med. 1997;11(3):217-224.
Negro S, Reyes R, Azuara ML, Sánchez Y, Barcia E. Morphine, haloperidol and hyoscine N-butyl bromide combined in s.c. infusion solutions: Compatibility and stability. Evaluation in terminal oncology patients. Inter J Pharma. 2006;307(2):278284.

Negro S, Salama A, Sánchez Y, Azuara ML, Barcia E. Compatibility and stability of tramadol and dexametaxone in solution and its use in terminally ill patients. J Clin Pharm Ther. 2007:32(5):441-444.

Schrijvers D, Tai-apin C, De Smet MC, Cornil P, Vermorken JB, Bruyneel P. Determination of compatibility and stability of drugs used in palliative care. J Clin Pharm Ther. 1998;23(4):311-314.

Singh S, Junwal M, Modhe G, Tiwari H, Kurmi M, Parashar N, Sidduri $\mathrm{P}$, et al. Forced degradation studies to assess the stability of drugs and products. Trends Anal Chem. 2013;49:71-88.

Statgraphics ${ }^{\circledR}$ Centurion XVIC 2010 StatPoint Technologies, Inc. Available from http://www.STATGRAPHICS.com.

Received for publication on $21^{\text {st }}$ June 2017 Accepted for publication on $02^{\text {nd }}$ November 2017 